\title{
A new species of Epilobium (Onagraceae) from Ulleungdo Island, Korea, Epilobium ulleungensis
}

\author{
Jae-Min Chung*, Jae-Kwon Shin, Eun-Mi Sun and Hoe-Won Kim ${ }^{1}$ \\ Korea National Arboretum, Pocheon 11186, Korea \\ ${ }^{1}$ Division of Life Sciences, School of Life Sciences, Korea University, Seoul 02841, Korea \\ (Received 6 March 2017; Revised 18 May 2017; Accepted 19 June 2017)

\section{한국(울릉도)의 1 신종: 울릉바늘꽃} \\ 정재민 ${ }^{*} \cdot$ 신재권 · 선은미 · 김회원 ${ }^{1}$ \\ 국립수목원, ${ }^{1}$ 고려대학교 생명과학대학 생명과학부
}

\begin{abstract}
A new species, Epilobium ulleungensis J. M. Chung (Onagraceae Juss), from Ulleungdo Island (South Korea) was described and illustrated. Among four taxa native to Ulleungdo Island (E. amurense Hausskn. subsp. cephalostigma (Hausskn.) C. J. Chen, Hock \& P. H. Raven, E. hirsutum L., E. pyrricholophum Franch. Sav., and E. ulleungensis), E. ulleungensis has a unique tetragonal stigma, which is considered to be an intermediate form between clavate (E. pyrricholophum) or capitate (E. amurense subsp. cephalostigma) and 4-lobed stigmas (E. hirsutum). More importantly, this new species is clearly distinguished from the other three taxa distributed on Ulleungdo Island by its height (over $200 \mathrm{~cm}$ ), decumbent stem, leaf shape, short, dense pubescent covering on the whole plant, large flower size, and a dark pink or red purple flower. According to the stigma shape and other characters, it was estimated that E. ulleungensis is a hybrid between E. hirsutum and E. pyrricholophum or E. amurense subsp. cephalostigma). The specific epithet "ulleungensis" was chosen because the new species was restricted to Ulleungdo Island.
\end{abstract}

Keywords: Onagraceae, Epilobium ulleungensis, new species, hybrid, Ulleungdo Island

적 요: 경상북도 울릉군에서 바늘꽃과 바늘꽃속의 신종인 울릉바늘꽃(Epilobium ulleungensis J. M. Chung) 을 발견하여 기재 및 도해하였다. 울릉도에 분포하는 바늘꽃속 4분류군(바늘꽃, E. pyrricholophum; 돌바늘 꽃, E. amurense subsp. cephalostigma; 큰바늘꽃, E. hirsutum; 울릉바늘꽃, E. ulleungensis)중에서 울릉바늘 꽃의 주두는 4 각형으로서 곤봉형인 바늘꽃 또는 두상형인 돌바늘꽃과 4 개로 깊게 갈라지는 큰바늘꽃의 중 간 형태를 보이고 있다. 중요하게도, 울릉바늘꽃은 $200 \mathrm{~cm}$ 이상의 큰 키와 비스듬히 누운 줄기, 잎의 형태, 식물체 전체의 짧은 밀모, 그리고 꽃의 크기와 진분홍색 또는 붉은 자주색의 꽃 색은 울릉도에 분포하는 다른 3 분류군과 명확하게 구별된다. 주두의 형태와 다른 분류학적 형질들에 의해 울릉바늘꽃은 큰바늘꽃과 바늘꽃 또는 돌바늘꽃과의 잡종으로 추정되었다. 신종의 자생지가 울릉도인 점을 고려하여 'ulleungensis'이 라 신칭하였다.

주요어: 바늘꽃과, 바늘꽃속, 신종, 울릉도, 울릉바늘꽃

*Author for correspondence: rhuso@korea.kr 
The family Onagraceae Juss. is composed of approximately 650 species worldwide (Chen et al., 1992, 2007). The tribe Epilobieae differs significantly from the six other tribes of the family, because it has minute, heteropycnotic chromosomes (Kurabayashi et al., 1962). The genus Epilobium L. is one of two genera currently recognized in the tribe Epilobieae (Solomon, 1982). Epilobium is the largest genus in the Onagraceae (Raven, 1976; Solomon, 1982), consisting of ca. 150-200 species in sub-polar to tropical regions (Raven, 1988; Hoch and Raven, 1992; Baum et al., 1994). Species of the genus have large numbers of small, easily dispersed, tufted seeds, and are characterized by vigorous vegetative perennation (Keating et al., 1982). Many hybrids of the genus have been reported (Schmitz, 1988; Krahulec, 1999; Mckean, 1999; Kitchener, 2003). The stigma shape in Epilobium has served as an important taxonomic key character among species of the genus (Chen et al., 1992, 2007; Lee et al., 2013)
On the Korean Peninsula, ca. 6 to 16 species of Epilobium have been recognized (Nakai, 1909; Chung, 1957; Lee, 1980). More recently, Lee et al. (2013) reported eight taxa native to the peninsula: E. pyrricholophum (바늘꽃), E. amurense subsp. amurense (호바늘꽃), E. amurense subsp. cephalostigma (돌 바늘꽃), E. fastigiatoramosum (회령바늘꽃), E. glandulosum var. asiaticum (줄바늘꽃), E. hirsutum (큰바늘꽃), E. palustre (버들바늘꽃), and E. platystigmatosum (가는민바늘꽃).

On Ulleungdo Island, three species of Epilobium have been recognized: E. amurense subsp. cephalostigma, E. hirsutum, and E. pyrricholophum (Chung et al., 2011). Since 2005, we have surveyed the flora on Ulleungdo Island and reported a total of 487 native vascular plant taxa (422 species) and 36 endemic plant taxa on the island (Chung et al., 2011).

Ulleungdo Island, located $120 \mathrm{~km}$ east of the Korean Peninsula, is a volcanic island of $73 \mathrm{~km}^{2}$. Because of its maritime climate, many temperate deciduous plants and warm-

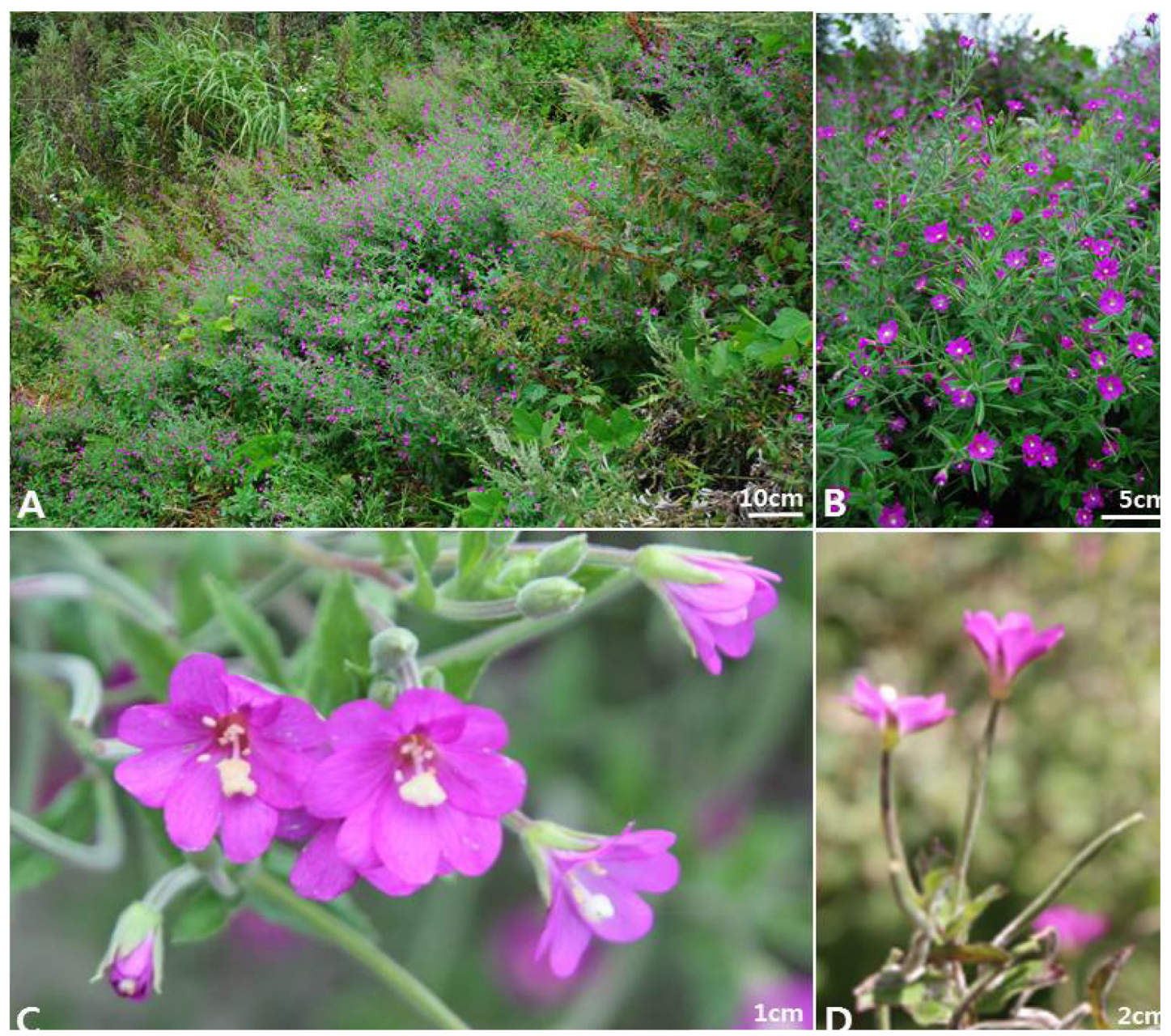

Fig. 1. Photographs of Epilobium ulleungensis J. M. Chung in its natural habitat on Ulleungdo Island. A. Habitat. B. Habit. C. Flower, front view. D. Flower, side view. 


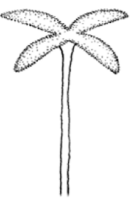

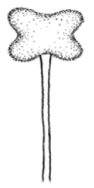

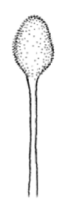

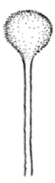

$1 \mathrm{~mm}$

Fig. 2. Stigma shape of four species of Epilobium. A. E. hirsutum. B. E. ulleungensis. C. E. pyrricholophum. D. E. amurense subsp. cephalostigma.

temperate plants occur on the island, forming a distinctive flora (Lee and Yim, 2002). In 2009, I discovered a morphologically distinct species of Epilobium on Ulleungdo Island (Fig. 1). It has a unique tetragonal stigma and is distinct from $E$. pyrricholophum with a clavate stigma, from $E$. amurense subsp. cephalostigma with a capitate stigma, and from $E$. hirsutum with a 4-lobed stigma (Fig. 2). Other characteristics (such as height over $200 \mathrm{~cm}$, relatively short [7.9-9.5 cm] lanceolate to long elliptic leaf shape, dark pink or red purple petal, and loosely villous pubescent surface) were distinguished from E. hirsutum (Table 1, Figs. 1, 2). According to the stigma shape and other characters, it was conjectured that $E$. ulleungensis is a hybrid between E. hirsutum and $E$. pyrricholophum or E. amurense subsp. cephalostigma). In the future, we will conduct karyotypic and molecular genetic studies to prove that this species is a hybrid. Therefore, presently, we described the taxon restricted to Ulleungdo Island as a new species, E. ulleungensis J. M. Chung.

\section{Taxonomic Treatment}

Epilobium ulleungensis J. M. Chung, sp. nov. (Figs. 1-4). TYPE: KOREA. Gyeongsangbukdo Province, Ulleungdo Island, $37^{\circ} 30^{\prime} \mathrm{N}, 130^{\circ} 50^{\prime} \mathrm{E}$, elev. $368 \mathrm{~m}$. 4 Aug 2016, Chung J. M. JMC15101 (holotype: KH; isotypes: KH [2 sheets]).

Korean name: Ul-leung-ba-neul-kkot 울릉바늘꽃.

Diagnosis: Epilobium ulleungensis is clearly distinguished from its related taxa by its tetragonal stigma, over $200 \mathrm{~cm}$ tall

Table 1. Comparison of some morphological characteristics between Epilobium ulleungensis and its related species, E. hirsutum, E. pyrricholophum, and E. amurense subsp. cephalostigma.

\begin{tabular}{|c|c|c|c|c|c|}
\hline \multicolumn{2}{|c|}{ Characters } & \multirow{2}{*}{$\begin{array}{c}\text { E. ulleungensis } \\
215-250\end{array}$} & \multirow{2}{*}{$\frac{\text { E. hirsutum }}{25-120(250)}$} & \multirow{2}{*}{$\begin{array}{c}\text { E. pyrricholophum } \\
24-80\end{array}$} & \multirow{2}{*}{$\begin{array}{l}\text { E. amurense subsp. } \\
\text { cephalostigma }\end{array}$} \\
\hline Plant height $(\mathrm{cm})$ & & & & & \\
\hline \multirow[t]{4}{*}{ Leaf blade } & shape & Lanceolate to oblong & $\begin{array}{l}\text { Lanceolate-elliptic to } \\
\text { narrowly obovate or } \\
\text { elliptic }\end{array}$ & Ovate to broadly oblong & Ovate to narrowly oblong \\
\hline & length $(\mathrm{cm})$ & $7.9-9.5$ & $4.0-12(23)$ & $2.1-4.6$ & $3.0-9.5$ \\
\hline & width $(\mathrm{cm})$ & $2.5-2.8$ & $0.3-4.0(5.0)$ & $0.7-2.0$ & $0.5-2.5$ \\
\hline & hairs & $\begin{array}{l}\text { Villous pubescent or } \\
\text { tomentose }\end{array}$ & $\begin{array}{l}\text { Densely villous pubescent } \\
\text { or white tomentose }\end{array}$ & Strigillose & $\begin{array}{l}\text { Subglabrous with } \\
\text { strigillose }\end{array}$ \\
\hline \multirow[t]{2}{*}{ Flower } & length $(\mathrm{cm})$ & $2.1-3.2$ & $1.2-1.5$ & $0.9-1.4$ & $0.8-1.3$ \\
\hline & color & $\begin{array}{l}\text { Deep-pink to red } \\
\text { purple }\end{array}$ & Pink to dark purple & Pink to purple & $\begin{array}{l}\text { White, pink or rose- } \\
\text { purple }\end{array}$ \\
\hline Petal & length $(\mathrm{cm})$ & $1.1-1.6$ & $0.8-2.0$ & $0.5-0.8$ & $0.5-0.8$ \\
\hline \multirow[t]{2}{*}{ Sepals } & length $(\mathrm{cm})$ & $0.8-1.2$ & $0.6-1.2$ & $0.3-0.6$ & $3.3-6.1$ \\
\hline & width $(\mathrm{cm})$ & $2.5-3.0$ & $0.9-1.2$ & $0.1-0.15$ & $0.9-1.3$ \\
\hline Pedicel & length $(\mathrm{cm})$ & $0.5-12$ & $0.5-2.0$ & $0.7-1.5$ & $0.3-1.3$ \\
\hline Style & length $(\mathrm{mm})$ & $7.8-8.2$ & $5.0-9.0$ & $1.5-3.7$ & $1.2-2.6$ \\
\hline \multirow[t]{2}{*}{ Stigma } & length $(\mathrm{mm})$ & $2.0-3.0$ & $1.0-4.0$ & $0.7-2.8$ & $0.9-2.2$ \\
\hline & shape & Tetragonal & 4-lobed & Clavate & $\begin{array}{l}\text { Capitate or broadly } \\
\text { capitate }\end{array}$ \\
\hline \multicolumn{2}{|c|}{ Filament length $(\mathrm{mm})$ short stamens } & $3.5-4.0$ & $2.5-4.4$ & $1.1-2.6$ & $0.9-2.2$ \\
\hline & long stamens & $5.5-7.0$ & $7.0-8.0$ & $2.1-3.3$ & $1.7-3.1$ \\
\hline Capsule & length $(\mathrm{cm})$ & $2.8-6.5$ & $2.5-9.0$ & $2.6-6.7$ & $4.2-6.7$ \\
\hline Seed & length $(\mathrm{cm})$ & $0.9-1.2$ & $0.8-1.2$ & $1.5-1.8$ & $0.8-1.0$ \\
\hline
\end{tabular}




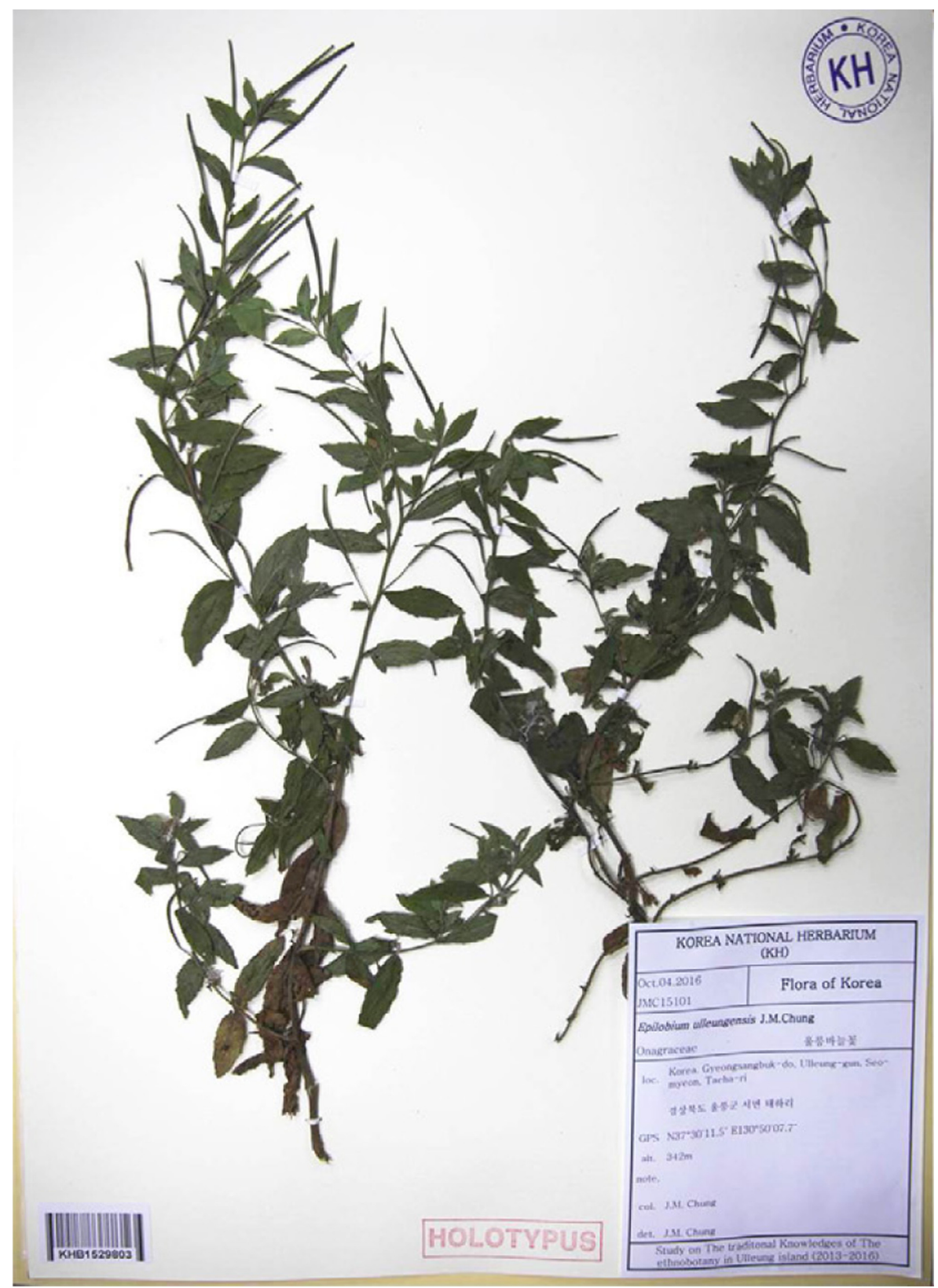

Fig. 3. Holotype of Epilobium ulleungensis J. M. Chung.

height, decumbent stem, lanceolate to oblong leaf blade, short and dense pubescent covering on the whole plant, a large flower size, and a dark pink or red purple flower (Figs. 2, 4).

Herbaceous perennial with clumped, leafy, basal soboles. Stem 2.2-2.4 m tall, decumbent, well-branched, pubescent with villous or tomentose trichomes. Leaves simple, opposite, sessile or clasping stem. Cauline leaves, blade lanceolate to oblong, $79-95 \times 25-28 \mathrm{~mm}$, base rounded, clasping, margin serrulate with $10-60$ teeth per side, apex acute to acuminate, adaxial surface rarely pubescent, deep green, abaxial surface pubescent, margin serrulate or denticulate. Inflorescence terminal and axillary, solitary, ebracteate; pedicels 5-12 $\mathrm{mm}$ long, pubescent. Flowers erect, actinomorphic; sepals 4, fused, 8.0-12 × 2.5$3 \mathrm{~mm}$, slightly keeled, lanceolate, pubescent; petals 4 , dark pink to purple, 11-16 $\times 9-12 \mathrm{~mm}$, obcordate; stamens 8, heteromorphic in lengths; filament $3.5-4.0 \mathrm{~mm}$ in short stamens, 5.5-7.0 mm in long stamens; anther 1.2-1.6 mm long, dehiscent along longitudinal slit; ovary inferior; style $8 \mathrm{~mm}$ long; stigma tetragonal, 2.0-3.0 $\times 2.5-3.0 \mathrm{~mm}$. Fruit capsules, 


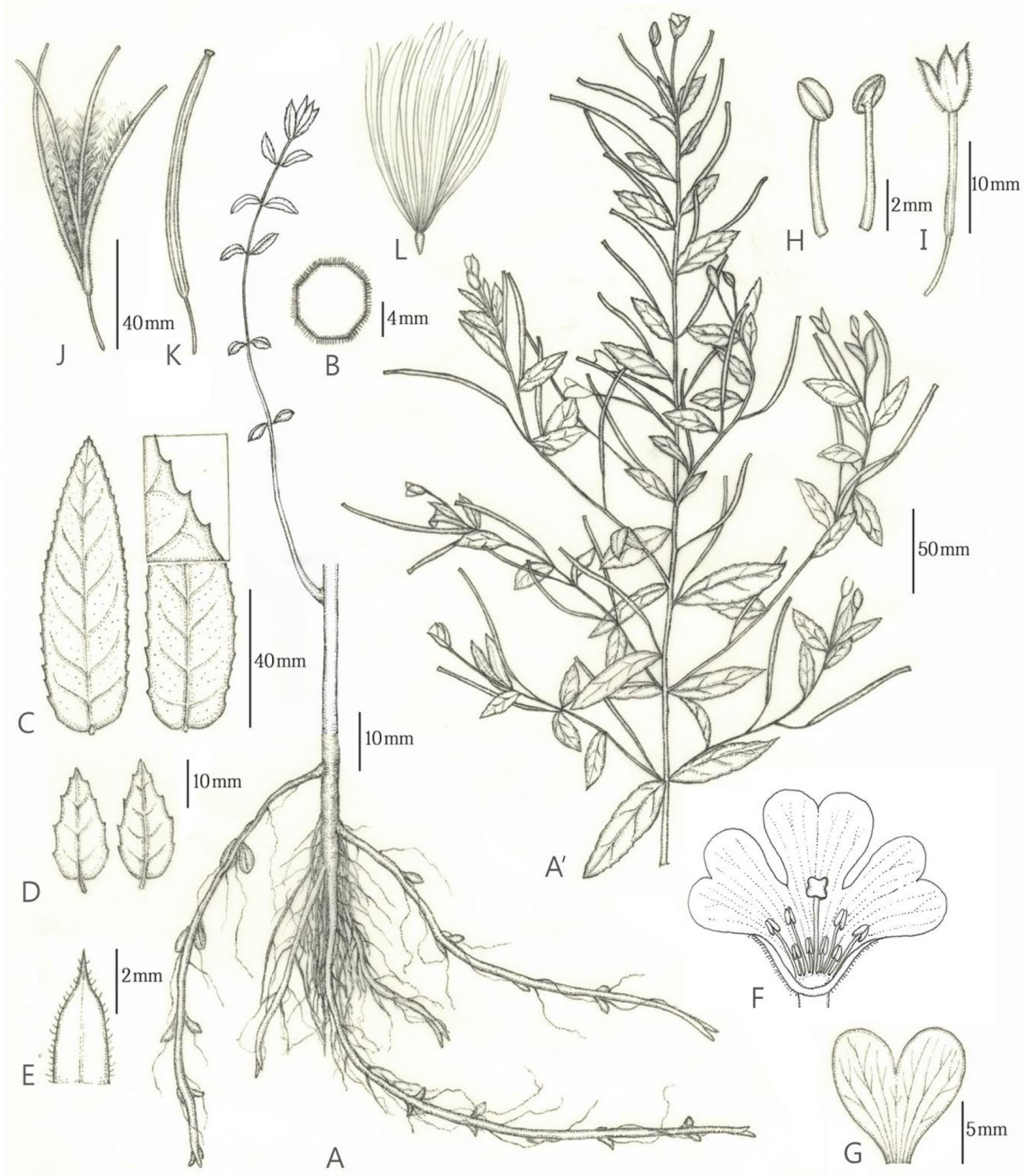

Fig. 4. A, A'. Habit. B. Cross section of stem. C. Cauline leaf. D. Bract. E. Sepal. F. Flower. G. Petal. H. Stamen. I. Pistil. J. Loculicidal dehiscence of capsules. K. Capsules. L. Seed.

$2.8-6.5 \mathrm{~cm}$ long, pubescent. Seeds numerous, dark brown, ovoid, 9.2-40.6 mm long, surface finely papillose, chalazal collar $6.0-8.7 \mathrm{~mm}$ long. Flowering July to Sep, fruiting Aug to Oct.

Additional specimens examined: Korea, Gyeongsangbukdo, Ulleungdo Island, $37^{\circ} 30^{\prime} \mathrm{N}, 130^{\circ} 50^{\prime} \mathrm{E}$, elev. $368 \mathrm{~m}, 22 \mathrm{Aug}$ 2011, Chung J. M. JMC12781 (KH); 9 Sep 2009, Chung J. M. JMC11310 (KH).

Habitat: A population of E. ulleungensis was found on a humid slope beside a stream in the upper part of Taeha valley on Ulleungdo Island (Fig. 1A). There were several populations of E. ulleungensis along the valley in the past. The number and size of the population has gradually decreased due to the agricultural road construction and farmland development. At present, the population area is ca. $3 \mathrm{~m} \times 7 \mathrm{~m}$ and its size fewer than 100 individuals because of clonal reproduction by runners sprouted from the lower part of the stem. Moreover, the population has been greatly threatened by the pressure of 
surrounding vegetation such as Hovenia dulcis, Albizia julibrissin, Boehmeria spicata, Pueraria thunbergiana, Miscanthus sinensis var. purpurascens, Dystaenia takeshimana, and Artemisia montana, etc. Therefore, a plan for in and ex situ conservation of the natural population of E. ulleungensis is required.

Distribution: Korea (Ulleungdo Island), endemic to Korea.

Etymology: The specific epithet is derived from Ulleungdo Island where this new species is located.

\section{Key to Epilobium ulleungensis and its related taxa}

1. Stem erect, less than $2 \mathrm{~m}$ tall. Stigma deeply 4-lobed,

$$
\text { E. hirsutum (큰바늘꽃) }
$$

1. Stem erect, less than $2 \mathrm{~m}$ tall. Stigma entire or shallowly emarginate

... 2

2. Stem decumbent, over $2 \mathrm{~m}$ tall. Stigma tetragonal … E. ulleungensis (울릉바늘꽃)

2. Stem erect, stem less than $1.5 \mathrm{~m}$ long. Stigma clavate or capitate

3. Leaves ovate or broadly oblong to lanceolate, sharply serrulate. Stigma clavate

E. pyrricholophum (바늘꽃)

3. Leaves ovate to oblong-lanceolate, apex acute or acuminate. Stigma capitate

… E. amurense subsp. cephalostigma (돌바늘꽃)

\section{Acknowledgments}

The author thanks Dr. Myong-Gi Chung for the helpful comments on the manuscript. This research was supported by research grants titled "The establishing Foundation to secure Sovereignty on the Traditional Knowledge of Ethnobotany in Korea (KNA1-1-11, 13-1)" and "Studies on the Conservation of Plant Species Diversity and Ecosystem of the Experimental Forest of Ulleungdo Island and Mt. Jumbongsan (KNA1-2-5, 08-5)" from the Korea National Arboretum.

\section{Literature Cited}

Baum, D. A., K. J. Systsma and P. C. Hoch. 1994. A phylogenetic analysis of Epilobium (Onagraceae) based on nuclear ribosomal DNA sequences. Systematic Botany 19: 363-388.

Chen, C.-J., P. C. Hoch and P. H. Raven. 1992. Systematics of Epilobium (Onagraceae) in China. Systematic Botany Monographs 34: 1-209.

Chen, C. J., P. C. Hoch and P. H. Raven. 2007. Epilobium L. In Flora of China, Vol. 13. Wu, Z. Y., P. H. Raven and D. Y.
Hong (eds.), Science Press, Beijing and Missouri Botanical Garden Press, St. Louis, MO. Pp. 400-419.

Chung, J. M., U. T. Kang, K. W. Park, M. S. Kim and B. C. Lee. 2011. A Checklist of the Native Vascular Plants of Ulleung Island, Korea. Samsung Adcom, Seoul. Pp. 43-99.

Chung, T. H. 1957. Korean Flora, Part 2, Herbaceous Plants. Shinjisa, Seoul. Pp. 431-439. (in Korean)

Hoch, P. C. and P. H. Raven. 1980. A new combination in Epilobium (Onagraceae). Madroño 27: 146.

Keating, R. C., P. C. Hoch and P. H. Raven. 1982. Perennation in Epilobium (Onagraceae) and its relation to classification and ecology. Systematic Botany 7: 379-404.

Kitchener G. D. 2003. A new Epilobium (Onagraceae) hybrid: Epilobium brunnescens (Cockayne) Raven \& Engelhorn $\mathrm{x}$ Epilobium parviflorum Schreber (E. $x$ argillaceum). Watsonia 24: 519-523.

Krahulec F. 1999. Two new hybrids of Epilobium ciliatum (Onagraceae). Preslia, Praha 71: 241-248.

Kurabayashi, M., H. Lewis and P. H. Raven. 1962. A comparative study of mitosis in the Onargraceae. American Journal of Botany 49: 1003-1026.

Lee, S., K.-I. Heo, S. Lee, M. Yoo, Y. Kim, J. S. Lee and S.-C. Kim. 2013. Taxonomic studies of tribe Epilobieae Endl. (Onagraceae) in Korea based on morphology and seed microstructure. Korean Journal of Plant Taxonomy 43: 208-222.

Lee, T. B. 1980. Illustrated Flora of Korea. Hyangmunsa, Seoul. Pp. 566-570. (in Korean)

Lee, W. C. and Y. J. Yim. 2002. Plant Geography with Special Reference to Korea. Kangwon National University, Chuncheon, 412 pp.

Mckean D. R. 1999. A new Epilobium hybrid from Scotland, E. pedunculare A. Cunn. x E. montanum L. Watsonia 22: 417419.

Nakai, T. 1909. Flora Koreana I. Journal of the College Science, Imperial University of Tokyo 26: 1-304.

Raven, P. H. 1976. Generic and sectional delimitation in Onagraceae, tribe Epilobieae. Annals of the Missouri Botanical Garden 63: 326-340.

Raven, P. H. 1988. Onagraceae as a model of plant evolution. In Plant Evolutionary Biology. Gottlieb, L. D. and S. K. Jain (eds.), Chapman and Hall, New York. Pp. 85-107.

Schmitz U. K. 1988. Dwarfism and male sterility in interspecific hybrids of Epilobium. 1. Expression of plastid genes and structure of the plastome. Theoretical and Applied Genetics 75: $350-356$.

Solomon, J. C. 1982. The systematics and evolution of Epilobium (Onagraceae) in south America. Annals of the Missouri Botanical Garden 69: 239-335. 